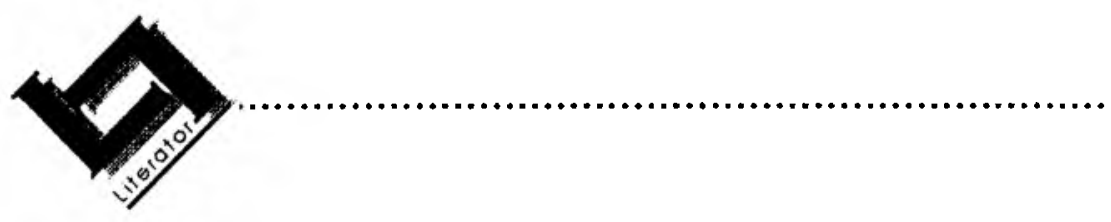

\title{
Also sprach Treppie: Taal en verhaal as muurpapier in Marlene van Niekerk se Triomf (of "it's all in the mind")
}

\author{
Willie Burger \\ Departement Afrikaans \\ Randse Afrikaanse Universiteit \\ JOHANNESBURG \\ E-pos: wdb@|w.rau.ac.za
}

\begin{abstract}
Also sprach Treppie: Language and narrative as wall paper in Marlene van Niekerk's Triomf (or, "it's all in the mind")
\end{abstract}

In Martene van Niekerk's Triomf "wall paper" becomes a central metaphor for the idea that language, narratives, ideologies, religion etc. are lies, because it leads to generalisations. These generalisations deny "reality" and are in Treppie's words "all in the mind". Treppie's efforts to tear down the wall paper could be described in Nietzschean terms as resistance to Apollinian veils (especially the veils of Christian national ideology) in order to expose Dionysian chaos. It is a resistance to any form of generalisation and a distrust of language. In the end Treppie tums to language (poetic language) in order to make sense of life, to lay bare the particular. In poetry (literature) an intersubjectivity is discovered which subverts the possibility to deny the specificity of individuals like the Benade's of Triomf.

\section{Muurpapier}

Op 'n Saterdagaand staan Treppie en Lambert op die stoep van hulle huis in Triomf en kyk na die huise rondom hulle. Lambert staar in die hoop om meisies te sien wat aantrek vir hulle uitgaanaand, maar Treppie sê dat hy vir die muurpapier in hulle kamers kyk:

Hy weet nie hoe Treppie so fyn kan sien nie, maar hy sê dit is net boompies en dammetjies en bruggetjies en hasies wat spring op groen grassies en eendjies en goed. Biou bergies in die verte. Dis nou op die muurpapier. 
For fucking crying in a bucket, sê hy dan, hoe kan mense hulleself so voorlieg met mure vol mock paradise (851).

Treppie is voortdurend in verset teen dit wat hy "muurpapier" noem. Daar is ' $n$ hele aantal begrippe wat in Triomf met "muurpapier" in verband gebring word (o.a. stories, "perspektiewe", gediggies en liedjies, koerantstories, "life support system", "bubbles", "white wash", die naam van die woonbuurt "Triomf", televisieprogramme, "painting sonder einde", geskiedenis en godsdiens). Telkens word met hierdie begrippe verwys na die onvermoë of onwil van mense om die waarheid, die lewe soos dit werklik is, in die oë te kyk. Muurpapier verwys na 'n verontagsaming van die individuele mens of gebeurtenis deur dit onder 'n veralgemening te verdoesel.

Die titel van die roman dui op die woonbuurt, Triomf (nou weer Sophiatown). Triomf is so genoem ná die gedwonge verskuiwings van swart mense uit die destydse Sophiatown. Sophiatown is platgestoot en op die puin daarvan is die sub-ekonomiese woonbuurt vir blankes, Triomf, gevestig. Volgens Lambert is daar net "rubble" onder hulle huis (1). Treppie wys op die ironiese betekenis van die naam Triomf:

Maar dit kom daarvan, sē hy, as jy 'n plek soos diè, vol prefabwiele en aalwyne, vrot van die rubble, 'n naam gee soos Triomf. Dan dink mense mos hulle het licence om vir hulleself te lieg. Maar dis kak daai, want al licence wat tel, is poetic licence (86).

Treppie verduidelik dat "poetic license" is om dinge met mekaar te laat rym wat nie met mekaar kan rym nie. 'n Bietjie later sê hy ook dat niks eintlik rym nie: "Eintlik rym daar niks van die hele wêreld of die sterre nie" (86). Om te rym, om woorde, name aan dinge toe te ken, om die werklikheid te bemiddel deur taal, is eintlik om te lieg. Hierdie uitspraak van Treppie herinner aan Nietzsche se idee dat elke begrip ' $n$ leuen is omdat dit ontstaan uit die gelykstelling van die nie-gelyke ("Jeder Begriff entsteht durch Gleichsetzen des Nicht-Gleichen" - vgl. Megill, 1987:49).

Dit is interessant dat die muurpapier-beeld ook deur Martin Versveld gebruik word in sy opstel "Oor patriotisme" (Versveld, 1975:107). Versveld verwerp denkstrukture wat op abstraksies geskoei is:

Omtrent hierdie dinge het ek bale by daardie groot pro-Boer G.K. Chesterton geleer. Die filosofie van sy Boergesindheid lê alles in hierdie paar woordjles opgesluit: 'Tennyson was right about the

1 Bladsynommers tussen hakies, sonder outeur of datum, verwys na: Van Niekerk, $M$. 1994. Triomf. Kaapstad: Queillerie. 
flower in the crannied wall, but most people don't look at the flowers in a wall, but only in a wall-paper. If you generalise them they are dull, but if you see them they are always startling.' As jy 'n ding generalise, dan sit jy hom onder ' $n$ generaal. (...) Wat dit alles vir my geleer het, is dat die keuse nie tussen liberalisme en nasionalisme lê nie. Dit waartussen jy moet kies, is abstraksie en werklikheid. Dit waartussen jy moet kies, is ' $n$ idee wat met emosionele vooroordele besmet is, en liefde vir werklike dinge en werklike mense.

Vir Versveld (soos vir Treppie) is muurpapier dus ' $n$ veralgemening wat 'n mens verhoed om die besondere raak te sien. Liberalisme en nasionalisme is veralgemenings wat ' $n$ ontkenning van die individuele mens is. Triomf is 'n roman waarin veralgemening ten koste van die individuele, die verberging van die individuele onder muspapier, ten sterkste ondermyn word. Treppie beskou onder andere godsdiens en politiek as veralgemenings wat die individualiteit van die Benades, die arm inwoners van Triomf, ontken.

In hierdie bespreking van Triomf wil ek, na aanleiding van die aangehaalde sleutelfrase (p. 85-86), die klem laat val op die volgende aspekte:

- 'n Ondersoek van die "muurpapier-metafoor", die idee dat taal, verhale, ideologieë eintlik leuens is aangesien veralgemenings daardeur ontstaan ("all in the mind") waardeur die werklikheid ontken word.

- Die wyse waarop Treppie in verset is teen die bedekking van die werklikheid met leuens, en hoedat hy daarop uit is om die muurpapier af te trek en die chaos (die "rubble") daaragter bloot te lê.

- Die wyse waarop die (woord)kuns ("poetic licencen") tóg 'n manier is om met die werklikheid om te gaan, aan die hand van Treppie se toevlug tot (poëtiese) taal.

In hierdie bespreking wil ek aandui dat Triomf ten nouste gemoeid is met die twintigste-eeuse taalteorie en uiteindelik onder andere gaan oor die rol van kuns (hier spesifiek die woordkuns) om die wêreld vir ons 'n leefbare plek te maak. Enersyds word, aan die hand van Treppie se idee van muurpapier, uitgebeeld hoedat taal tekort skiet om die werklikheid te medieer; hoedat elke vorm van ideologie en godsdiens eintlik maniere is waarop mense hulleself "voorlieg" met "mock paradise". Andersyds word getoon hoedat kuns uiteindelik ons enigste greep is op die werklikheid. 
Binne hierdie verband is die werk van Nietzsche ${ }^{2}$, veral sy opvatting van die Dionisiese en Apolliniese, verhelderend. Treppie (wat dikwels deur Mol as 'n "dywel" beskryf word ${ }^{3}$ ) kan in 'n sekere sin beskou word as 'n "Dionisiese monster" of Zarathustra (Nietzsche, 1992:26).

Nietzsche stel in sy eerste werk, The Birth of Tragedy (1992:1-145), die Dionisiese teenoor die Apolliniese 4 . Binne die estetika en die kultuurfilosofie dui die terme Appolinies en Dionisies volgens Van Gorp $(1984: 30)$ op twee polêre geestestipes, wêreldbeskouings of kunstenaarstipes. ' $n$ Dionisiese instelling (afgelei van die god Dionisus) is een van "roes, extase en bedwelmend zinnelijke beleving. Felle bewogenheid, expressieve vormgeving en het verlangen naar ontgrenzing creëren". Hierteenoor dui Apollinies (afgelei van die god Apollo) op "een houding waarop rede, begrenzing en evenwicht hun stempel drukken".

In sy studie van die tragedie (The Birth of Tragedy) gaan Nietzsche (1992:33) uit van die idee dat die ontwikkeling van kuns ten nouste verbonde is aan die Apollinies-Dionisiese dualiteit. In hierdie werk redeneer Nietzsche dat die ou Grieke 'n Apolliniese beskawing gehad het wat hulle onderskei het van die "barbare" rondom hulle. Die barbare rondom hulle het "dionisies" geleef. Vir die Grieke het die Apolliniese die Dionisiese getemper. Die barbare bly barbare omdat die Dionisiese onbeperk voortgaan. In die Griekse beskawing word die Dionisiese deur die Appolliniese aangewend - die impulse van Dionisus word gebruik, getransformeer om 'n bestanddeel van kultuur te word eerder as ' $n$ uitdrukking van natuur.

Apollo beskerm dus die Grieke teen barbaarsheid - maar dit beteken dat die Grieke in 'n illusie geleef het - dat alle kultuur op illusie gegrond is. Apollo beskerm ons dus met illusies teen die harde realiteit van bestaan. Dit wat Treppie "muurpapier" noem, kan dus in verband gebring word met die Apolliniese, die versluiering van die skrikwekkende werklikheid. Die werklikheid, wat voortdurend deur allerhande vorms van muurpapier bedek word, impliseer vir Treppie dat ons bestaan eintlik sinloos is:

2 Nietzsche word dikwels beskou as voorloper van die denke wat oorheersend geword het in die twintigste eeu - vergelyk onder andere Megill (1987) en Vattimo (1988).

3 Louise Viljoen (1994:54) noem Treppie 'n "soort Mefistofeles".

$4 \quad$ In sy latere werk staan die twee nie meer skerp teenoor mekaar nie maar word die Apolliniese as't ware opgeneem binne 'n beskouing van die Dionisiese as die kreatiewe ordening van passie en 'n aangryp van die lewe - iets waarop aan die einde van hierdie bespreking weer teruggekeer sal word aangesien dit ook ' $n$ aspek is wat in verband met Treppie gebring kan word. 
"Asem in, asem uit, eet, kak, eet, kak, tjorts, weg! Niemand het daarvoor gevra nie" (358).

\section{Muurpapier en die Apolliniese / realisme vs. idealisme}

"Muurpapier", in die sin waarin Treppie die term in Triomf gebruik, hou verband met die Apolliniese houding van sluiers wat oor die werklikheid getrek word, met die gevolglike beperking van die mens se ervaring van die lewe. Deur veralgemenings (in Versveld se terminologie) word die individuele werklikheid ontken. Hierdie veralgemenings, muurpapier, is die leuens wat voorgehou word om mense te manipuleer, om hulle die werklikheid anders te laat ervaar as wat dit in der waarheid is. Muurpapier is misleiding, die verdoeseling van die realiteit, ' $n$ realiteit wat, in Treppie se woorde, "n pokput" is (359).

In Triomf is daar 'n skerp teenstelling tussen die muurpapier, die idealisme, dit wat "all in the mind" is (en wat in verband gebring kan word met Nietzsche se beeld van die Appolliniese) aan die een kant, en die realisme, "die suiwer onverdunde en ewige waarheid sonder woorde" (322) aan die ander kant. Ook in die aanhaling uit Versveld se opstel (hierbo) lê die keuse tussen abstraksie en werklikheid.

Weens die beperkte ruimte van 'n artikel wys ek as voorbeeld slegs na die Christelike-nasionale ideologie as muurpapier en dan kortliks na ander "soorte" muurpapier.

\section{Christelik-nasionale muurpapier}

Ná sy pa hom geslaan het, kon Treppie nooit weer "God van Jakob" en "Afrikaners landgenote" sing nie, want "dit was nou muurpapier daardie" (300). Sowel godsdiens as (Afrikaner-)nasionalisme is dus vir Treppie muurpapier. Die verwysing na juis 'n gesang en 'n volksliedjie hier in een asem, dui op die Christelik-nasionale ideologie wat vir Treppie bloot muurpapier is. Die Christelik-nasionale is ' $n$ vorm van 'n Apolliniese sluier oor die werklikheid, 'n sluier wat mense blind maak vir die realiteit. Hierdie "-isme" is ' $n$ veralgemening, ' $n$ keuse vir ' $n$ abstraksie, ' $n$ idee bo die werklikheid.

\subsection{Godsdiens}

Dit is nie bloot godsdiens in die sin van die Christelik-nasionale verbintenis wat deur Treppie as muurpapier beskou word nie. Treppie verset hom ten sterkste teen godsdiens omdat dit voortdurend oordele uitspreek en beloftes maak wat nie waar word nie, wat nie verband hou met die werklikheid nie. Hy merk byvoorbeeld op dat 'n Kersfeesboom 
(weer 'n simbool, muurpapier) misleidend is, omdat dit nie na 'n "electrical trick" is wat mense soek nie, maar na Jesus (254). Ook die vergifnis van sonde wat deur godsdienste verkondig word, beskou Treppie as muurpapier, as iets wat die kerke verkoop. Die kerk is vir hom "n tak van Morkels. Vergifnis op 'n special. Halleluja, prys die Heer. One payment down, elke kollekte" (364). Treppie stel vergifnis inderdaad gelyk aan muurpapier (363). Vergifnis bied geen verbetering in die hier en nou van die lewe nie. Hy vergelyk vergifnis met 'n motreën na dertig jaar se droogte. Die motreën laat almal beter voel maar het nie regtig 'n effek op die droogtetoestand nie (363-364).

Treppie se verset teen godsdiens as murpapier, as versluiering van die werklikheid, vind ook neerslag in sy travesterende beskouing van die "yskasboek" as die familiebybel (315). Treppie se travestie van katkisasie en belydenis van geloof dien om verder te bevestig dat godsdiens met die metafisiese gerigtheid daarvan net woorde is - muurpapier en versiering, valse hoop. Op dieselfde manier wat kennis van die yskasboek die hoop op verlossing uit hulle armoedige, ellendige bestaan gebied het (hulle sou ryk word deur yskaste te herstel), bied godsdiens ook 'n hoop, om die hemel te bereik. Die Benades se hoop om in Triomf 'n "hemel op aarde" te vind, beskaam - is muurpapier. Die hoop wat godsdiens bied, is eintlik hopeloos, juis omdat dit nie rekening hou met die werklikheid nie maar gerig is op ' $n$ hiernamaals. Deurgaans in die roman blyk dat godsdienstige beloftes nie die lewe (die hier en nou) vir mense beter maak nie. Alles bly maar net soos dit is. Woorde is leuens dié van die politiek en dié van die godsdiens. Die NP's en Jehovas se gereelde besoeke bevestig dat godsdiens en politiek beloftes van hoop bring, beloftes van Triomf en Hemel bring, maar die hoop word (nie alleen deur Treppie se konfrontasies met die NP's en die Jehovas nie maar ook deur die romangebeure) blootgelê as "muurpapier", "all in the mind".

Die godsdiens bring ook moraliteit ter sprake. Tydens die "bergpredikasies"5 word Treppie deur Pop gekonfronteer met die vraag wat mens behoort te doen (359):

(...) as daar nou een woord is wat jy nie voor Treppie moet sê nie, is dit 'behoort". Nou, toe's dit of hy terpentyn op sy stert gekry het.

'Behoort,' sẽ hy, 'behoort se moer! As jy doodgaan, gaan jy dood, punt, uit. Maar jy skuld niemand nikse gebehoort nie. Want jy't dit nie

5 Uiteraard reeds 'n verwysing na godsdiens: Jesus se bergpredikasie in Matteus 5-7. 
bestel nie, nie om gebore te word nie en ok nie om jou lewe lank te lewe in hierie pokput nie.'

Hiermee word Treppie se verset teen enige metafisiese beloftes (muurpapier) baie duidelik. In hierdie lewe, die "pokput", kan daar nie sprake wees van 'n moraliteit wat bepaal word deur 'n metafisiese maatstaf van buite hierdie wêreld nie. Dit is waarom Treppie ook vir Mol en Pop dwing om na die letsels op sy lyf te kyk - hy bevestig daarmee sy verankerdheid in die liggaamlike belewenis, die hier en nou as vertrekpunt, eerder as in 'n veralgemenende abstraksie. Sy letsels en pyn is nie muurpapier nie. Treppie se verset teen die sluier van 'n godsdiens, of van 'n moraliteit en 'n verantwoordelikheid wat bepaal word deur 'n hiernamaals, staan ook in 'n nou verband met Nietzsche se werk.

The Birth of Tragedy is, volgens Nietzsche self (in die voorwoord wat hy dertien jaar later vir die heruitgawe geskryf het), 'n filosofie wat dit waag om moraliteit te beperk tot die domein van fenomene, met ander woorde 'n moraliteit wat nie berus op ' $n$ maatstaf van buite hierdie wêreld nie. Vir Nietzsche behoort moraliteit egter nie net tot die domein van fenomene nie, maar The Birth of Tragedy is ook ' $n$ ondersoek na moraliteit as misleiding en bedrog:

(...) a philosophy that dares to move, to demote morality to the realm of appearance - and not merely among 'appearances' or phenomena (in the sense assigned to these words by Idealistic philosophers), but among 'deceptions', as semblance, delusion, error, interpretation, contrivance, art (Nietzsche, 1992:22-23).

Hierdie aanvaarding van 'n antimorele houding staan direk teenoor die Christelike leer. Die Christelike leer gaan uit van 'n moraliteit wat reeds voor die skepping bestaan. Volgens Nietzsche het die Christelike leer absolute standaarde wat kuns beoordeel, relegeer en ignoreer. Volgens so ' $n$ redenasie is die ganse lewe gebaseer op misleiding, voorstelle en perspektiewe. Hierdie lewe word afgewys ten gunste van 'n ander, beter lewe. Dit lei tot die afwysing van genot en passie en tot vrees vir skoonheid en sensualititeit. Die "ander lewe" word die maatstaf vir hierdie lewe en lei gevolglik tot haat van hierdie lewe. Vir Nietzsche is die erkenning van slegs "morele waardes" soos deur die Christelike leer toegepas, die gevaarlikste "wil tot ondergang". Dit lei tot 'n verarming van die huidige lewe:

For confronted with morality (especially Christian, or unconditional, morality), life must continually and inevitably be in the wrong, because life is something essentially amoral - and eventually, crushed by the weight of contempt and the eternal No, life must then be felt to be unworthy of desire and altogether worthless (Nietzsche, 1992:23). 
Moraliteit (gegrond op 'n "ander" wêreld) is dus ' $n$ wil tot die ignorering van die lewe, 'n beginsel van agteruitgang. Daarom is moraliteit so gevaarlik vir Nietzsche.

Treppie wys ook moraliteit - veral die Christelike moraliteit - voortdurend af. Treppie stel nie belang in die woorde "goed en sleg" nie. Hy sê "dinge is soos hulle is en klaar" (56). Hy sê selfs dat die hemel 'n plek is waar hy nie wil wees nie - dit sal immers 'n plek sonder enige kuns wees, sonder enige kans om met woorde te speel.

Triomf is daarom veel meer as bloot ' $n$ afwysing van apartheid. Eintlik is die afwysing van apartheid, die effek van apartheid wat hier gedemonstreer word, ' $n$ illustrasie van wat gebeur as daar nie meer kuns is nie as die moraliteit in 'n absolute verander sodat dit nie meer moontlik is om aan ander moontlike wêrelde te dink nie. Die skrikwekkende teenoorgestelde van kuns word dan waar - muurpapier. Muurpapier impliseer meer as bloot die toeplak van die werklikheid - dit is ' $n$ vernietiging van die oorspronklike denke, van die vermoê om ander perspektiewe te hê. Muurpapier lei tot die skrikwekkende enkele afwysing van die lewe, afwysing van die kreatiewe antwoord op ons bestaan. Muurpapier is (soos die Christelike moraliteit vir Nietzsche is) die begin van die einde, 'n wil om die lewe te negeer: "a secret instinct of annihilation, a principle of decay, diminution, and slander - the beginning of the end (...) Hence the danger of dangers?" (23).

Vir Nietzsche (1992:24) is die Dionisiese 'n gerigtheid teen moraliteit. Nietzsche beskou sy verset teen moraliteit as ' $n$ instink wat aan die kant van die lewe staan - wat 'n waarde in die lewe ontdek.

It was against morality that my instinct turned with this questionable book (The Birth of Tragedy - WDB), long ago; it was an instinct that aligned itself with life and that discovered for itself a fundamentally opposite doctrine and valuation of life - purely artistic and antiChristian. What to call it? (...) I called it the Dionysian.

In Triomf word die gevolge van 'n geloof in die moraliteit van 'n "ander wêreld", wat 'n miskenning van hierdie wêreld is, blootgelê. Mense wat geloof het in een of ander saak wat met woorde "uitgeborduur" is, sal enigiets vir dié saak doen, redeneer Treppie. Wanneer Lambert luister na 'n goed uitgeborduurde saak, wys Treppie op die effek van hierdie "geloof" in woorde: "... hy (Lambert) sal nou fokken ladybirds vreet as jy dit vir hom sê" (316). 


\subsection{Politieke retoriek (en geskiedenis) as muurpapier}

Treppie leer nie net af om "God van Jakob" te sing nie, maar ook om "Afrikaners landgenote" te sing. 'n Verheerliking van die Afrikanergeskiedenis en die opsweping van gemoedere deur "geborduurde" politieke retoriek, is vir Treppie muurpapier. Dit was gedurende die 1938ossewatrek dat hulle "God van Jakob" en "Afrikaners landgenote" "so aanmekaar moes sing in die skole" (300). Treppie sê dat dit nie sy "scene daai" was nie: "Dit was nou vir jou muurpapier daai if you ever wanted interior decoration" (300). Treppie het ook nie deelgeneem aan die feesvierings soos die res van sy familie nie. Hy was skaars tien jaar oud maar het toe al besef dat dit alles "muurpapier" is. Oor die res van sy familie sê hy: "Een vir een fok hulle mos soos skape agter die vuur in die wolk aan. En in sy familie kom dit al van vér af, die fokken hans houding" (300). Treppie sê dat hy die dag met die Ossewatrek geleer het:

... jy kan van enige fokken ding 'simbolies' maak as jy wil, vanaf ' $n$ piepot tot 'n posbus. En dit hang net af of jy genoeg mag het, dan kan jy nog 'n verkiesing ok wen met 'n simboliese piepot. Of 'n hosepipe op 'n kruiwa of bobbejaanspanner. It's all in the mind (301).

Treppie is sinies oor die idee van 'n simboliese trek, maar brei hierdie sinisme ook uit na alles wat in die Afrikanergeskiedenis opgeneem is: "Mense moenie met daai tipe kak by hom kom nie. Met Jopie Fourie en Racheltjie de Beer en Johanna van der Merwe nie" (301).

Die manier waarop Treppie die republiekwording in 1961 benader, getuig ook van sy wantroue in enige politieke bestel (44-45). Hy spot vir Pop en Mol omdat hulle die verkoop van blomme met Republiekdag sien as "n saak". Treppie verwys telkens neerhalend na Pop of Mol (soos Oupop voor hulle) se geloof in die Nasionale Party of optrede van die regering. Hy sê vir Lambert dat die twee lede van die NP wat hulle gereeld kom besoek, nie beter is "as huisagente wat agter kommissie aan is" nie (288-289). Vir Treppie is dit duidelik dat al die politieke retoriek misleidend is en hy neem vir Pop en Mol kwalik daarvoor dat hulle in 1948 "geval het, hook line and sinker, vir Malan se storie. Wéér 'n Groot Trek-storie" (306). Die "nuwe" van die Nasionale Party is vir Treppie "dieselfde gemors, gerecycle onder 'n ander naam. Maar die gemors self is 'n brandless substance" (307). Steeds val die klem op die "name" wat aan dinge gegee word en wat, volgens Treppie, 'n "brandless substance" is, met ander woorde ' $n$ werklikheid wat nie 'n naam het nie, wat nie deur woorde teenwoordig gestel word nie maar wat bedek word, versluier word deur die veralgemenende name wat daaraan gegee word.

Wanneer Treppie die "mathematics of history gekliek" het (307), besef hy ook dat alles wat die politici sê, bloot name is wat lieg: "Die hele wêreld 
is net name en niks is wat dit is nie en alles is wat dit nié is nie, it's all in the mind! En die mind is 'n bottomless pit" (309). Treppie besef dat die regering nog nooit iets daadwerkliks gedoen het om hulle posisie te laat verbeter nie, maar dat die Nasionale Party nietemin probeer om hulle stemme te werf. Al die retoriek oor die Afrikanergeskiedenis, die opsweping van emosies deur simboliek (om uiteindelik stemme te werf) is vir Treppie bloot muurpapier, 'n Apolliniese siuier oor die werklikheid.

\section{Stories, drome, advertensies, televisie ...}

Mol vertel graag stories om beter te voel, soos haar goeie herinneringe aan die verkoop van rose (40). Die verkoop van die blomme was eintlik net om weg te kom van al die sleg van haar bestaan (42/43). Sy verkies om nie aan die slegte sy te dink nie. Sy ontsnap dus van die realiteit deur haar positiewe herinneringe, deur ook vas te hou aan drome oor byvoorbeeld die hemel. Pop help om haar drome te onderhou. Hy onthou byvoorbeeld $\mathrm{Mol}$ se verjaarsdag en gaan koop vir haar 'n roosboom as geskenk (302). Wanneer Treppie vir Mol sê hulle moet liewer die roosboom nêrens plant nie aangesien dit in elk geval sal doodgaan, begin Mol huil. Treppie vertel haar dan van hemelse roosbome wat verskillende kleure rose dra en al hoe beter groei hoe meer "hemelse hondepie" hulle kry: "Een aanmekaar nimmereindigende storie embroider hy vir haar", hy "spin [...] vir haar 'n klomp kak" (303). Deur hierdie (onwaar) stories te vertel, troos Treppie vir Mol. Treppie weet dat hierdie stories leuens is maar dat dit vir haar troos bring. Die TV-advertensies is ook vir Mol 'n droom van 'n wêreld waar sy alleen op haar eie bed kan slaap, sonder dat iemand met haar lol, 'n voorreg wat sy nooit in haar lewe gesmaak het nie (165). Hierdie drome en stories is leuens, muurpapier waardeur die werklikheid verdoesel word.

Lambert sien homself soos 'n karakter in films. Mol moet vir hom "stories" vertel van die cowboys en daarop improviseer ten einde sy bloedskandige seks met haar te laat anders lyk. Ook sy verwagting van die meisie wat hulle vir hom bring, word geraak deur sy idees van wat in die "movies" aangaan; 'n movie waarin hy "die unknown hero" is (371). Lambert droom van sy "mermaid" wat nie sal wees soos die almanakmeisies nie. Dit is vir haar wat hy alles "opfix". Dit is 'n droom wat sy bestaan rig maar dan word dié lugborrel geprik. Lambert droom om 'n "ordentlike huis" van die plek te maak - "met lampshades" (352). Hy glo in sy drome dat wanneer hy die "girl" kry, alles sal regkom. Sy hoop is gevestig op 'n droommeisie - al werk die droom nie so goed uit nie, want die meermin se verf dop voortdurend af en sy ma vertel nie die stories reg na sy sin nie. Uiteindelik kan hy egter nie met die meisie (reg)kom nie. Die leuens van dinge wat nie werklik is nie, word ook geillustreer 
deur die bubbles wat Lambert se Fuchs maak. In die weerkaatsings van hierdie "bubbles", lyk sy hele kamer anders - selfs die lendelam, vuil bed lyk soos 'n "lovenest". Dan bars die "bubble" van sy drome en daar is niks daarvan oor nie (339). Uit hierdie insident blyk ook die misleiding van drome en stories wat vertel word - dat verhale en drome ook eintlik muurpapier is.

\subsection{Perspektiewe}

Die grootste stuk muurpapier in die lewe van die Benades is die leuen wat hulle voorhou, naamlik dat hulle 'n gesin is. Hierdie leuen noem Treppie hulle "perspektief". Die perspektief wat hulle vir Lambert gee oor wie sy ouers werklik sou wees, hoe die familiebande in mekaar steek, is ' $n$ leuen waarin hulle self naderhand op ' $n$ manier glo. Dit is volledig uitgewerk en ingeoefen met selfs 'n toespraak wat Treppie op die troue sou gelewer het (163). (Dit kan ook allegories geinterpreteer word as die land se geskiedenis wat deur die ouer generasies aan 'n jonger een voorgehou (en ingeoefen) word maar wat onwaar is.) Die onthulling van hierdie "perspektief" as muurpapier, as bedekking van die waarheid van die gesinsamestelling, lei tot die katastrofale slot van die roman. Wanneer die Apolliniese sluier vir 'n oomblik gelig word en Lambert gekonfronteer word met die werklikheid, is hierdie realiteit vir hom te angswekkend om te hanteer en hy reageer soos hy altyd reageer wanneer hy gekonfronteer word met die (vir hom) onverstaanbare: hy gebruik geweld om alles te probeer regsien en vererger die situasie in die proses.

Lambert maak ook die "painting sonder einde" waarin al sy drome saamgevat word. Die skilderwerk is teen die muur en kan daarom ook as 'n vorm van muurpapier beskou word. Wanneer dinge nie uitwerk soos hy dit in die muurskildery gevisualiseer het nie, skiet hy die pleister van die muur af.

Uiteindelik is die wit waarmee hulle huis geverf word ook in der waarheid muurpapier. Die werklikheid word deur die verf bedek, maar eintlik verander dit niks aan hulle situasie nie. Treppie dink aan die herstelwerk van die huis:

Met ' $n$ face-lift gaan daar tog altyd iets verlore, en wat kan hulle tog nou verloor in any case? Nou nie wat jy museum pieces sal noem nie, net collected works of wear and tear. Die bietjie baggage van die Groot Trek van die Benades, vuil gevat, swart gebrand, gekoek, taai, blink gesit, gekraak, uitgetorring. Mot en roes met hondehare oor alles. 
Nie muurpapier dié nie. Ok nie 'n tabernakel nie. Net die blues van Marthastraat 127. Fine print van fokol. Droesem van Triomf! (306).

Om die huis af te wit, is dus dieselfde as om 'n nuwe dorp op Sophiatown se "rubble" te bou en dit dan Triomf te noem. Dit is 'n leuen.

\subsection{Rympies, koerantlees, woorde}

Treppie is voortdurend besig om rympies te maak, te verdraai en met woorde te speel. Lambert noem Treppie immers met trots 'n "poet". Treppie se beskouing van woorde herinner aan Derrida se radikalisering van die Saussureaanse idee dat woorde slegs na woorde verwys, slegs in terme van woorde beskryf kan word en voortdurend finale betekenis uitstel:

Dis sy fokken end, die alewige geneuk met woorde. In hierdie land het elke ding mos ' $n$ naam wat eintlik 'n ander ding se naam is. Pik Botha, Vleis Visagie, Slang van Zyl, Brood van Heerden. En vat nou maar húlle name. Pop het wragtag nooit enige pop in hom gehad nie. En Mol kan traai soos sy wil, maar sy sal nooit 'n hopie geskop kry nie. (...) Lambertus Benade, klink na 'n ambassadeur of iets met 'n ruiker in sy knoopsgat, maar almal kan sien dis meer as ' $n$ misnomer, dis 'n fokken misgebóórte. Sy eie naam is 'n totale fokop. (...) waar moet dit eindig? Die hele wêreld is net name en niks is wat dit is nie en alles is wat dit nié is nie, it's all in the mind (308-309).

Wanneer Treppie op die toilet sit en koerantlees, besef hy dat die mens deur 'n stortvloed van niksseggende woorde mislei word:

Legio soos die varke van Gadara is die name van goed, en hulle moer by die troppe aanmekaar bo-op mekaar af in daai put. 'n Losgemaal in die dieptes. Nie die asem werd wat hulle mee gesê word nie, never maaind die papier waarop hulle geskryf is! (309).

Treppie gooi al die koerante teen die plafon in 'n daad van magteloosheid teen die stroom van nuttelose woorde. Wanneer hy die koerante opskeur, "woordconfetti" daarvan maak (310), lei dit daartoe dat sy maag werk. Die vernietiging van die woorde lei tot dit wat hy graag realiteit noem, die een woord wat "all side same side" is, "kak": "die maan is 'n naam, lag is gal, our lord is ' $n$ drol, net kak is all side same siden (273). Teenoor die woordimperialisme van die idealisme staan die inkarnasie in die vorm van Treppie se hardlywigheid. ' $n$ Mens is juis liggaamlik en daarin is die primère belewing van die werklikheid geleë. Dit blyk duidelik dat dit onmoontlik is om te ontsnap van hierdie realiteit waaraan hulle uitgelewer is: "Anything you say, Triomf of Doris Day, ons is hier om te blyl" (273). Dit is swaartekrag wat hulle in Triomf vashou en daar is nie uitkomkans nie (119). 


\section{Verset teen muurpapier}

Treppie is ten sterkste in verset teen "muurpapier". Hy beskou dit as sy taak om almal voortdurend daaraan te herinner dat hulle beskouings veralgemenings is wat nie verband hou met die individuele ervaring nie. Die waarheid is dat die lewe "kak" is. Vir Treppie is die manier hoe dinge bloot is, van belang. Die manier waarop die dinge beskryf word, is "all in the mind":

Cloud Nine is die wolk se naam waarop hy sy hele lewe al wil gewees het, maar hy't geleer (...) hy't geleer it's all in the mind, die ins en outs van dinge, dit hang net af watter name jy dinge gee (173).

Die verset teen muurpapier is ' $n$ verset teen die veralgemening, die masker van die Apolliniese. In Nietzscheaanse terme is hierdie verset geleë in die moment wanneer Dionisus die sluier van Apollo wegtrek. Die aftrek van die muurpapier is dus die ontmaskering van die Apolliniese as blote sluier

'n Belangrike insident in hierdie verband is wanneer Treppie sy hemp oplig en vir Pop en Mol dwing om na die letsels te kyk (361). Dit is die realiteit geanker in die persoonlike ervaring. Geen verhaal kan dit beter maak, anders laat lyk, of wegneem nie. Dit sal 'n ontkenning van die pyn en werklikheid van die lewe wees. Dit is nie 'n werklikheid waarvoor mens kan wegkruip of kan terugdeins nie. Die "shame" van Mol (woorde) help nie.

\subsection{Aftrek van muurpapier}

Volgens Lambert het Treppie 'n liedjie wat hy altyd sing as "hy wil hê mense moet hulle oë oopmaak" (438). Vir Treppie is dit van die allergrootste belang dat mense "hulle oë moet oopmaak", dat die werklikheid, die (liggaamlike) lewe van pyn en lyding, die hier en nou, bepalend moet wees vir handeling en nie een of ander metafisiese troos nie. Hy wil die wêreld probeer sien soos dit is, nie toelaat dat woorde soos muurpapier die werklikheid bedek nie. Daarom voer hy ook uiteindelik aan dat hy moeg is vir die "geheim", die "perspektief" op/van die gesin. Hy beskryf hierdie perspektief as 'n "life support system" (423) en "'n life support system" is 'n "leuen teen die waarheid van die dood en dit red jou nie uit jou definitiewe einde nie" (423). Muurpapier bied geen verlossing uit die werklikheid van ons lewens nie. Dit is nie die moeite werd om in die aangesig van die dood enigiets te ontken en te gryp na "life support systems" nie. Die hele skepping is "n automatic cycle en 'n closed circuit, perpetual motion" (400). 
Treppie begin om geheime, leuens wat oor jare opgebou is, te ontmasker - dit breek Lambert se wêreld en hulle kyk na mekaar oor "'n vloer vol stukkende Coke-bottels tussen hulle" $(60)$. Treppie probeer om die "perspektief" te "bebogger" (407). Hy besef dat die waarheid moet uitkom - dat Lambert die hele storie moet hoor sodat daar 'n einde aan die muurpapier kan kom.

Wat Treppie aan die gang hou, is om hulle almal se gevoelens (met die hulp van Lambert) bloot te lê sodat hy "hulle kan sien vir wat hulle is" (108). Treppie is op soek na 'n ongemedieerde werklikheid, om te sien soos dinge werklik is. Hy wil van die Apolliniese sluier ontslae raak, die muurpapier aftrek en die individue, elke Benade, raaksien, nie veralgemenings nie. Uiteindelik is dit ook wat met die leser gebeur. Die leser leer nie armblankes in Triomf ken nie, maar vir Treppie, Pop, Mol en Lambert.

\subsection{Teenstrydigheid in Treppie se verset}

Ten spyte daarvan dat Treppie homself enersyds rig op die aftrek van muurpapier, lyk dit andersyds of hy ook 'n skepper van muurpapier is. Dit is 'n paradoks wat Treppie self verklaar deur aan te voer dat hy "lieg om waarheidsontwille" (434). Pop sê Treppie moes 'n clown geword het "wat lag en huil vir dieselfde ding solat mense nie hulle minds kan opmaak nie. En dis 'n goeie ding want hierie wêreld het nie mense nodig wat hulle minds om elke hoek en draai staan en opmaak oor boggerol nie ..." (319).

Dit is wel so dat Treppie telkens nuwe "angles" gee op die werklikheid, dat hy muurpapier skep, maar dan ondergrawe hy telkens weer hierdie perspektiewe. Wanneer Treppie vir Lambert in 'n hoek dryf op die oggend na die nag met die prostituut, besef Mol Treppie "gee vir hulle 'perspektiewe' en goed om hulle baste te red, maar dan moer hy dit weer pap en dan lag hy vir hulle" (408).

Treppie skep voortdurend narratiewe om moontlikhede uit te druk. Hy skep byvoorbeeld die "perspektief" - dit wat sin moet gee aan Lambert se bestaan. Ook die "noorde" waarheen hulle kan vertrek op die dag wat "die kak spat", is 'n voorbeeld van 'n narratief wat Treppie skep om die werklikheid te versluier. Hy vertel vir Mol van die hemel waar die rose in al die kleure groei. Treppie vernietig ook voortdurend hierdie narratiewe.

Treppie maak gebruik van die onsekerheid wat taal tot gevolg het. Die woorde van Treppie se "profesie" is vir hulle almal onleesbaar - dit is 'n rympie waarin Treppie sê dat daar nie genoeg "druk" (yskastaal) in Lambert is nie en dat Lambert nie in staat sal wees om iets met die 
meisie uit te rig nie. Treppie lê klem daarop dat hy presies bedoel wat "daar staan" (329). Hiermee word weer kommentaar gelewer op die bedrieglikheid en onvermoë om aan die werklikheid uitdrukking te gee deur taal. Dit word 'n demonstrasie daarvan dat elkeen net sien wat in sy/haar eie denke is, "it's all in the mind". Vir Lambert staan daar byvoorbeeld "fokol" (329).

Op pad huis toe van die stad af, besef Treppie dat hy ook iets nodig het om homself met die "aandster in lyn te kry" (106). Hy erken dus dat 'n visie nodig is, hy het ook behoefte aan 'n perspektief, al is daar niks op aarde of in die sterre wat rym nie. Treppie is dus bewus daarvan dat 'n mens wel 'n perspektief (taal / verhaal) nodig het om homself "in lyn te $k r y$ ". ' $n$ Mens is in daardie sin afhanklik van die Apolliniese. Dit is egter noodsaaklik om voortdurend daarvan bewus te wees dat so 'n perspektief, verhaal of storie, nie die werklikheid is nie. Taal veralgemeen, dit bring nie kontak met die realiteit nie. Dit is van tyd tot tyd nodig dat 'n mens weer bewus gemaak moet word van die chaos, van die "kak", en dat mens moet onthou dat die Apolliniese bloot 'n sluier is. Daarom is Treppie die nar wat mense laat lag en huil, wat vir die Benades "perspektiewe" gee en dit dan weer "pap moer". Daarom is Treppie 'n Dionisiese "Dywel".

Treppie se erkenning dat 'n "visie" noodsaaklik is, die troos wat Treppie vir Mol bied deur haar te vertel van die hemel, of die troos wat al die Benades vind in die "perspektief" op die gesin, kan beskou word as voorbeelde van Treppie se kreatiewe ingrype op die "vormlose", Dionisiese realiteit. Die probleem met enige van dergelike perspektiewe is vir Treppie daarin geleë dat dit uiteindelik so ernstig opgeneem kan word op 'n rigiede wyse, dat dit alle kreatiwitieit, alle pogings om 'n eie visie op die werklikheid af te dwing, ondermyn. Om hierdie rede laat hy nie toe dat enige van sy gesinslede gemaklik raak met 'n bepaalde visie nie, maar karring hy voortdurend aan hulle om weer "spark" uit hulle te kry (367).

Nietzsche stel in "Beyond Good and Evil" (1992:275) dat daar nie werklik "morele fenomene" is nie, maar bloot morele interpretasie van fenomene. Vir Nietzsche moet die keuse tussen goed en kwaad op estetiese grond geneem word en daarom is die vrye kreatiwiteit van die kunstenaar vir Nietzsche belangrik. Die persone wat morele kodes begin, is nie vir hom verwerplik nie. Hierdie persone was immers kreatief en het 'n eie idee van hoe die wêreld behoort te lyk op die "vormlose" realiteit afgedwing dit was 'n kreatiewe daad. Die probleem ontstaan vir Nietzsche wanneer enige visie verval in ' $n$ rigiede sisteem waarteen daar geen opstand geduld word nie - dan word kreatiwiteit gedood en dit is vir Nietzsche immorele optrede - om nie skeppend om te gaan met die wêreld nie. 
Kuns het dus vir Nietzsche "ontogenetiese betekenis" (Megill, 1987:31). Wat ontstaan, is die gevolg van die artistieke wil. Die gegewe, die werklikheid, is bloot die doek waarop geskilder word. Die wêreld is dus menslike skepping. Vir Nietzsche is die wêreld waarin ons leef iets wat voortdurend geskep en herskep word - en daar is niks agter hiedie "web van illusies" nie.

Treppie skep voortdurend nuwe visies, maar op 'n wrede manier herinner hy ook homself en en sy gesin daaraan dat dit bloot visies is. Dit herinner aan Nietzsche se opvatting van die seltvernietigende aard van die kunstenaar waaruit skoonheid ontstaan:

This secret self-ravishment, this artist's cruelty, this delight in imposing a form upon oneself as a hard, recalcitrant, suffering material and in burning a will, a critique, a contradiction, a contempt, a No into it, this uncanny, dreadfully joyous labor of a soul voluntary at odds with itself that makes itself suffer out of joy in making suffer $(. .$. also brought to light an abundance of strange new beauty and affimation, and perhaps beauty itself (Nietzsche, 1992:524).

\subsection{Treppie se vredesgedig}

Indien Treppie se projek bloot is om ander se muurpapier af te trek, "perspektiewe en goed" "pap te moer", kan uiteindelik geredeneer word dat Treppie op sy beurt glo dat sý visie van die werklikheid, sy weergawe daarvan waar is (en dat hierdie weergawe inderdaad weer net woorde is, steeds nie die realiteit nie). Pop keer inderdaad hierdie redenasie so om op Treppie tydens die bergpredikasies. Pop verduidelik dat Treppie altyd 'n "angle" het op 'n saak: "Hy sien altyd 'n hoek of 'n draai of 'n kant of 'n kleur aan 'n ding, al is daai ding hoe plat en wit en niks" (367). Pop lê verder ook klem op die belang van Treppie se vermoë om die wêreld op hierdie wyse uit 'n ander hoek te kan sien. Dit is, volgens Pop, belangrik dat Treppie voortdurend met almal skoor te soek en "trap en skop en lieg en [te] kere gaan in daai grondelose gat in, (...) totlat hy 'n spark uit dit uit kry" (367). Pop beskryf dus Treppie se rol as die een wat die "grondelose gat", die chaos van die werklikheid, voortdurend blootlê en verduidelik dat hierdie Dionisiese rol absoluut essensieel is vir sy eie voortbestaan maar ook vir die bestaan van die Benades. Juis omdat hy hierdie Dionisiese rol vervul, is hy die Benades se "vital ingredient" (366) en hulle "generator" (367).

Na Pop se "preek" sê Treppie dat dit nou te laat is vir trane en hy sit agter in die Volkswagen met 'n glimlag: "its never too late for a laugh" (370). Treppie is voortdurend besig om te vermaak, om in die aangesig van die mees afgryslike werklikheid te bly lag. Wanneer Lambert in die finale oomblikke (nadat hy die waarheid ontdek en Pop oor die kop met 
die laai geslaan het) sy aggressie (soos gewoonlik) teen die gesin rig, vir Mol met 'n mes steek en Treppie se vingers almal breek, lê Treppie "gebreekte vingers en al" en "huil soos hy lag" (444). Dit is in hierdie stadium wat Treppie boonop kwytraak: "Een dood, drie beseer" en "One down, three to go!" (444).

Die iaaste deel van Nietzsche se voorwoord tot The Birth of Tragedy is in dialoogvorm geskryf. Die skrywer van The Birth of Tragedy (as kunsvergoddeliker en pessimis) word aangespreek en afgevra of dit nie eintlik 'n diep wil tot destruksie is wat onderliggend aan die hele werk is nie:

Is it not a deep bass of wrath and the lust for destruction that we hear humming underneath all of your contrapuntal vocal art and seduction of the ear, a furious resolve against everything that is 'now', a will that is not too far removed from practical nihilism and seems to say: 'sooner let nothing be true than that you should be right, than that your truth should be proved right!' (25).

Deur aan te haal uit The Bith of Tragedy vra hierdie stem die skrywer of hy nie eintlik maar probeer om 'n romantiek met pessimisme te verberg nie. (In Triomf se terme kan gevra word of Treppie nie ook maar muurpapier plak nie; glo hy nie ook maar in muurpapier - 'n romantiese bedekking - nie? Het hy nie 'n geloof wat weggesteek word agter pessimisme, 'n defaitistiese pretensie, nie? Hy skryf immers self ook gedigte en speel met woorde en lees koerante en versamel woorde en skep perspektiewe?) Die vraag aan die skrywer van The Birth of Tragedy is eintlik of die skep van kuns nie maar weer 'n romantiese ideaal is nie. Dit is ook die vraag wat ons van Treppie kan vra. Die aanhaling getuig dat dit eventueel weer nodig gaan wees om 'n nuwe kuns, 'n metafisiese vertroosting, te begeer.

Nietzsche se antwoord is negatief. Hy sê dat dit nie nodig gaan wees vir so 'n nuwe geloof nie, maar dat dit waarskynlik weer in 'n geloof sal eindig. Nietzsche se raad is dat dit noodsaaklik is om te leer lag indien mens die pessimisme wil behou. Lag word deur hom voorgehou as die afwysing van metafisiese vertroostings. Deur te lag kan die metafisiese verleidings verdoem word:

No! You ought to leam the art of this-worddly comfort first; you ought to leam to laugh, my young friends, if you are hell-bent on remaining pessimists. Then perhaps, as laughers, you may some day dispatch all metaphysical comforts to the devil - metaphysics in front (Nietzsche, 1992:26). 
Zarathustra, uit Nietzsche se later werk, word aangedui as die een wat "die kroon van lag" dra6. Treppie probeer om, soos Zarathustra, metafisiese hoop deur die lag af te wys. Die metafisiese, hetsy in die vorm van godsdiens of politiek, word verwerp. Treppie maak dit letterlik belaglik: Hy maak grappies van godsdiens se vergifnis deur na die belydenis van sonde te verwys as "one payment down" elke Sondag. Hy maak politieke retoriek belaglik deur die wyse waaarop hy die twee Nasionale Party-verteenwoordigers daar wegkry. Hy wys op die belaglikheid van die Ossewatrek en die republiekwording. (Hierdie beskouing herinner aan Milan Kundera se klem op die rol van die lag in romans ${ }^{7}$.)

Aan die een kant veg Treppie teen die "muurpapier" en is hy voortdurend besig om almal rondom hom se drome te prik. Maar aan die ander kant is dit hy wat 'n versie oor die lente langs die Westdenedam skryf. Treppie wend hom tog tot woorde wanneer hy die mooi dag langs die Westdenedam beskryf. Versveld (1975:110) redeneer dat veralgemenings (muurpapier) 'n "wêreld van ontpersoonlike objekte" tot gevolg het - 'n wêreld waarin alles "dood-gewoon" raak en die mens verveeld word. In werklikheid is niks egter net "gewoon" nie: "Gewone water is 'n abstraksie: daar bestaan nie so iets nie. Die digter moet oor gewone dinge skryf, en wat hy vir ons leer, is om binne hulle te woon, en 'n medesubjektiwiteit daar te vind ..." (Versveld, 1975:110). Dit is inderdaad wat Treppie met sy gedig aan die einde doen. "DIT IS NIE MUURPAPIER DIE NIE" (268) is 'n gedig oor die gewone - 'n gewone lentedag langs die gewone Westdenedam (juis nie 'n plek van buitengewone natuurskoon nie). Boonop plak Mol hierdie gedig teen die muur by die lugfoto van Johannesburg en sodoende word die gedig met die Benades se identiteit verbind. Hulle eie individualiteit, hulle eie plek binne die wêreld (die groter Johannesburg) waarbinne hulle verswelg word deur veralgemenings (hetsy as subekonomiese klas, as stemvee of "tipe"). Met hierdie gedig probeer Treppie om, soos Versveld van die digter verwag, ons te leer om "n medesubjektiwiteit" te vind eerder as om deur muurpapier verblind te word vir die individuele.

'n Deel van die triomf van Triomf is dat die roman juis die Benades uithef uit die veralgemenende groep van armblankes, van ' $n$ "soort" mens, en hulle as unieke individue aan lesers bekendstel - mense met ' $n$ eie posbus (die posbus word 'n belangrike merker van hulle identiteit in die roman).

Kundera (1995:3-33). 
Versveld (1975:110) voer ook aan dat niks wat bewoon word, gewoon kan wees nie. Die huisie wat uiteindelik afgewit word, wis die uniekheid van die Benades uit, maak hulle gewoon. Treppie se verset teen die groot gewoonmaak, die konformering volgens 'n sekere Apolliniese sluier, neem die vorm aan van 'n Dionisiese lag, die aftrek van die Apolliniese. Daarom is hy die "vital ingredient" wat, ten spyte van die pyn, die Benades in staat stel om hulle eie unieke self te wees.

Versveld redeneer in sy artikel dat die mens deur tegniese vaardigheid en ontwikkeling homself tussen hakies plaas en slegs aan die wêreld buite hom aandag gee. Hierdie modernistiese neiging is egter ' $n$ onmoontlikheid en die mens is altyd onderworpe aan 'n "antropomorfisme, die afdruk van die menslike beeld op die heelal" (Versveld, 1975:114). As ' $n$ mens jouself versmaai, so redeneer Versveld, sien jy die heelal skeef. Treppie waak voortdurend daarteen dat die Benades vergeet wie en wat hulle is. Daarom is hy gedurig aan die "karring" met elkeen van hulle en daarom is hy bekommerd daaroor dat hy al hoe meer sukkel om "spark" uit hulle te kry. Die leuens van die muurpapier kan te maklik die veralgemenende manier word waarop hulle die wêreld sien - daarom moet hy die muurpapier aftrek. Hy probeer om voortdurend van hulle onmiddellike situasie uit te gaan - vanaf hulle huisie, vanuit die Groot Trek van die Benades die werklikheid te sien - eerder as om te swig voor die veralgemenings van godsdienstige of politieke retoriek. In hierdie retoriek is almal, veral die armes, die Benades, bloot abstraksies. Treppie besef dat sulke abstraksies leuens is. Versveld (1975:115) stel dat die waarheid 'n persoon, nie 'n abstraksie is nie ${ }^{8}$. Ook Treppie probeer die individu as waarheid, as vertrekpunt neem en verwerp alle abstraksies. Abstraksies, Apolliniese sluiers, moet "papgemoer" word sodat die allerindividueelste werklikheid gekonfronteer kan word.

\section{Bibliografie}

Kundera, Milan. 1995. Testaments Betrayed. London : Faber \& Faber.

Megill, A 1987. Prophets of Extremity: Nietzsche, Heidegger, Foucault, Derrida. Berkeley : University of Califomia Press.

Nietzsche, W.F. 1969. Thus Spoke Zarathustra. (Vertaal deur R.J. Hollingdale.) London : Penguin Books.

Nietzsche, W.F. 1992. Basic Writings of Nietzsche. (Vertaal deur Walter Kaufmann.)

New York: The Modern Library.

8 Binne die konteks van Versveld se raamwerk dui die "Persoon" op Christus. Waar Nietzsche dus abstraksies afwys deur onder andere die lag van Zarathustra, wys Versveld abstraksies af ten gunste van die individuele persoon - waarin Versveld vir Chrisus as vleesgeworde werklikheid binne die wèreld sien. 
Viljoen, Louise. 1994. Skroewe en brackets spat in Triomf. Die Suid-Afrikaan, 49:5354, Julie.

Van Gorp, H. 1984. Lexicon van literaire termen Groningen : Wolters-Noordhof.

Van Niekerk, Marlene. 1994. Triomf. Kaapstad : Quellerie.

Vattimo, G. 1988. The End of Modernity. London: Polity Press.

Versveld, Marthinus. 1975. Klip en klei. Kaapstad: Human \& Rousseau.

\section{Kernbegrippe:}

kuns as uitdrukking van die individuele

Nietzsche

taal / verhaal as illusie

Triomf (roman van Marlene van Niekerk)

veralgemening, in teenstelling tot die individuele

Key concepts:

Art as expression of individuality

generalisation, in juxtaposition to individuality

language / story as illusion

Nietzsche

Triomf (novel by Marlene van Niekerk) 